\title{
STUDI KEBERHASILAN PENGELOLAAN OBJEK WISATA PANTAI PANDAWA OLEH BUMDA KUTUH
}

\author{
Ryan Andhikautami Oktadesia ${ }^{1)}$, Priyendiswara Agustina Bela ${ }^{2)}$ \\ 1) Program Studi S1 PWK, Fakultas Teknik, Universitas Tarumanagara, utammyoktadesia@gmail.com \\ 2) Program Studi S1 PWK, Fakultas Teknik, Universitas Tarumanagara, hedi.agustina@yahoo.com
}

\begin{abstract}
Abstrak
Lokasi penelitian ini berada di Pantai Pandawa, Desa Kutuh, Kecamatan Kuta Selatan, Kabupaten Badung, Provinsi Bali. Adapun tujuan dari penelitian ini adalah untuk mencari faktor - faktor keberhasilan dari pada pengelolaan objek wisata Pantai Pandawa yang dilakukan oleh lembaga Desa Adat milik masyarakat yaitu BUMDA Kutuh. Untuk mendapatkan faktor - faktor keberhasilan pengelolaan objek wisata Pantai Pandawa oleh BUMDA Kutuh dilakukan melalui analisis - analisis. Analisis tersebut antara lain analisis kebijakan dari Pemerintah maupun dari Desa Adat terkait pengelolaan Pantai Pandawa, analisis daya tarik eksisting yang dimiliki oleh Pantai Pandawa, analisis kondisi dari pada pengelolaan dan persepsi serta kepuasan dari sisi pengunjung yang datang ke Pantai Pandawa, analisis pengelola dan masyarakat lokal terhadap pengelolaan yang dilakukan di Pantai Pandawa, analisis tolok ukur keberhasilan pengelolaan berbasis community based tourism, dan analisis kesesuaian antara faktor - faktor keberhasilan pengelolaan dengan pariwisata berbasis masyarakat berdasarkan penelitian terdahulu dengan pengelolaan yang dimiliki oleh objek wisata Pantai Pandawa. Untuk mencapai tujuan tersebut maka dilakukan beberapa analisis dengan menggunakan alat analisis seperti alat analisis deskriptif, alat analisis diagram kartesisus, dan CSI. Sehingga hasil dari analisis tersebut dapat digunakan untuk membuat rekomendasi faktor - faktor yang menentukan keberhasilan dari pengelolaan objek wisata Pantai Pandawa oleh BUMDA Kutuh milik Desa Adat Kutuh.
\end{abstract}

\section{Kata kunci: faktor keberhasilan; pariwisata berbasis masyarakat; tolok ukur keberhasilan}

\begin{abstract}
The location of this study is in Pandawa Beach, Kutuh Village, Kuta Selatan District, Badung Regency, Bali Province. Pandawa Beach which is carried out by a community-owned traditional village institution, BUMDA Kutuh. To get the success factors in managing Pandawa Beach tourism object by BUMDA Kutuh, it is done through analyzes. This analysis includes policy analysis from the Government and from the Customary Village related to the management of Pandawa Beach, analysis of the existing attraction that is owned by Pandawa Beach, analysis of the conditions of the management and assessment as well as satisfaction of visitors coming to Pandawa Beach, analysis of providers and local communities of management carried out at Pandawa Beach, analysis of the benchmarks of successful management based on community-based tourism, and analysis of the appropriateness of the factors of success management with community-based research related to research supported by Pandawa Beach attractions. To achieve these objectives, an analysis is carried out using analytical tools such as descriptive analysis, analysis diagram of the Cartesian analysis, and CSI. Pandawa Beach by BUMDA Kutuh is owned by Kutuh Customary Village.
\end{abstract}

\section{Keywords: benchmarks of success; community based tourism; success factors}

\section{PENDAHULUAN}

Berdasarkan data Badan Pusat Statistik (BPS) pada tahun 2018 jumlah desa yang ada di Indonesia berjumlah 75.436 desa yang terdiri dari 74.517 desa dan 919 nagari (Sumatera Barat). Untuk jumlah desa adat sendiri belum diketahui secara pasti karena tidak mendapatkan ketetapan secara hukum. Namun dari jumlah tersebut menurut Eko Putro 
Sandjojo selaku Menteri Desa, Pembangunan Daerah Tertinggal dan Transmigrasi (Mendes PDTT) hingga tahun 2019 tercatat berdasarkan data hasil pendataan Potensi Desa (Podes) 2018 oleh Badan Pusat Statistik (BPS) jumlah desa tertinggal sebanyak 13.232, desa berkembang 54.879 desa, dan desa mandiri sebanyak 5.559 desa.

Salah satu desa mandiri yang berhasil yaitu Desa Kutuh, merupakan desa yang ada di Kecamatan Kuta Selatan Kabupaten Badung, Provinsi Bali. Secara geografis desa ini letaknya berada di selatan Pulau Bali. Desa Kutuh berhasil dalam mengelola dan mengembangkan potensi sumber daya alam dan manusia yang dimiliki sehingga maju desanya. Berdasarkan sejarahnya, Desa Kutuh merupakan desa yang terdiri dari desa adat dan desa dinas. Desa ini dahulu miskin karena penduduk lokal yang bergantung pada mata pencahariannya sebagai petani rumput laut dan dari segi pendidikan warga desa juga terbatas.

Dengan sinergi pembangunan yang dihasilkan oleh para pemimpin desa adat dan desa dinas untuk membangun Desa Kutuh yang sejahtera, saat ini Desa Kutuh berhasil mendirikan lembaga desa adat yang di prakarsai oleh pemerintah desa dinas untuk mengelola potensi milik adat menjadi usaha desa, potensi yang dapat digali yaitu potensi pariwisata. Tujuan mengelola aset dan potensi pariwisata milik adat tersebut yaitu karena APBDES dari pemerintah yang diturunkan melalui desa dinas tidak cukup untuk keperluan desa dinas dan desa adat, karena untuk keperluan adat sendiri bisa memakan biaya hingga 3 miliar rupiah per tahun. Selain itu, pola desa adat mengharuskan aset-aset yang ada di sebuah desa disertifikasi atas nama masyarakat adat dan harus dimanfaatkan sehingga menghasilkan keuntungan untuk menghormati leluhur terdahulu, jadi semua potensi pariwisata milik adat harus dikelola oleh masyarakat adat sedangkan pemerintahan dinas hanya sebagai pembina maupun pelindung bagi masyarakat adat di Desa Kutuh.

Maka didasari latar belakang tersebut, dibentuklah BUMDA (Bhaga Utsaha Manunggal Desa Adat) selanjutnya disebut BUMDA sebagai lembaga desa adat hasil dari inovasi Desa Kutuh dalam pengelolaan ekonomi terintegrasi milik masyarakat adat. BUMDA juga sebagai holding company dari 8 unit usaha dan 2 layanan (tidak berorientasi bisnis), diharapkan BUMDA dapat menjadi pengendali dalam mengelola aset dan potensi pariwisata Desa Adat Kutuh.

Penelitian ini bertujuan untuk mengetahui daya tarik yang dimiliki oleh Pantai Pandawa, mengetahui manajemen pengelolaan yang dimiliki oleh Pantai Pandawa, mengetahui tolok ukur keberhasilan dan faktor faktor keberhasilan pengelolaan berbasis community based tourism dari Pantai Pandawa.

\section{KAJIAN LITERATUR}

\section{Pariwisata}

Berdasarkan undang-undang RI No 10 tahun 2009 Bahwa :

a. Pariwisata adalah berbagai macam kegiatan wisata dan didukung berbagai fasilitas serta layanan yang disediakan oleh Masyarakat, Pengusaha, Pemerintah Pusat, dan Pemerintah Daerah.

b. Wisata adalah kegiatan perjalanan yang dilakukan oleh seseorang atau sekelompok orang dengan mengunjungi tempat tertentu untuk tujuan rekreasi, pengembangan pribadi, atau mempelajari keunikan daya tarik wisata yang dikunjungi dalam jangka waktu sementara.

c. Kepariwisataan adalah keseluruhan kegiatan yang terkait dengan pariwisata dan bersifat multidimensi serta multidisiplin yang muncul sebagai wjenujud kebutuhan setiap orang dan negara serta interaksi antara wisatawan, Pemerintah, Pemerintah Daerah, dan Pengusaha.

d. Daya Tarik Wisata (DTW) adalah segala sesuatu yang memiliki keunikan, keindahan, dan nilai yang berupa keanekaragaman kekayaanalam, budaya, dan hasil buatan manusia yang menjadi sasaran atau tujuan kunjungan wisatawan.

e. Usaha pariwisata adalah usaha yang menyediakan barang dan jasa bagi pemenuhan kebutuhan wisatawan dan penyelenggaraan pariwisata. 


\section{Jenis Pariwisata}

Jenis-jenis pariwisata menurut Spillane (1987) berdasarkan tujuan perjalanan dapat dibedakan menjadi enam jenis, yaitu:

a. Pariwisata untuk menikmati perjalanan (Pleasure Tourism)

b. Pariwisata untuk rekreasi (Recreation Tourism)

c. Pariwisata untuk kebudayaan (Cultural Tourism)

d. Pariwisata untuk olahraga (Sports Tourism)

e. Pariwisata untuk urusan usaha dagang (Business Tourism)

\section{Daya Tarik Wisata}

Maryani (1991) menjelaskan bahwa objek-objek wisata yang merupakan unsur dari pariwisata tidak cukup hanya memiliki keunikan untuk menarik pengunjung, tetapi ada daya tarik lain yang harus dimiliki oleh objek-objek wisata tersebut, yaitu :
a. What to see
b. What to do
c. What to buy
d. What to Arrived
e. What to stay

\section{Pengelolaan Pariwisata Berbasis Community Based Tourism}

Pariwisata Berbasis Masyarakat (Community Based Tourism) menurut Hadiwijoyo (2012) adalah pengembangan masyarakat dengan menggunakan pariwisata sebagai alat untuk memperkuat kemampuan organisasi masyarakat lokal. Berdasarkan konsep pemberdayaan masyarakat dalam pembangunan kepariwisataan maka upaya pemberdayaan masyarakat melalui kepariwisataan pada hakikatnya harus diarahkan pada beberapa hal sebagai bertikut :

a. Meningkatnya kapasitas, peran dan inisiatif masyarakat pembangunan kepariwisataan;

b. Meningkatnya posisi dan kualitas keterlibatan/partisipasi masyarakat;

c. Meningkatnya nilai manfaat positif pembangunan kepariwisataan bagi kesejahteraan ekonomi masyarakat;

Meningkatnya kemampuan masyarakat dalam melakukan perjalanan wisata.

\section{Tolok Ukur Keberhasilan Community Based Tourism}

Berdasarkan Suansri (2003), pengelolaan berbasis community based tourism dikatakan berhasil apabila memenuhi lima aspek yaitu ekonomi, sosial, budaya, lingkungan dan politik. Dengan indikator dari masing - masing aspek sebagai berikut ini :

a. Aspek Ekonomi

Memiliki dana untuk pengembangan komunitas, dan harus terciptanya lapangan pekerjaan dan pendapatan masyarakat di sektor pariwisata.

b. Aspek Sosial

Memiliki penguatan organisasi dalam komunitas.

c. Aspek Budaya

Memiliki upaya pelestarian keunikan karakter dan budaya di area lokal.

d. Aspek Lingkungan

Memiliki kegiatan konservasi untuk menjamin keberlanjutan lingkungan.

e. Aspek Politik

Adanya partisipasi dari masyarakat lokal.

\section{Faktor - Faktor Keberhasilan Community Based Tourism}

Berdasarkan jurnal penelitian International Rural Tourism and Development Journal (IRTAD) yaitu tentang Success Factors of Community Based Tourism (CBT) Perceived by Local Peoples (2017), diketahui terdapat sepuluh faktor sukses keberhasilan dari pengelolaan berbasis community based tourism. Berikut merupakan faktor - faktor keberhasilan pengelolaan 
berbasis community based tourism :

Tabel 1. Faktor - Faktor Keberhasilan Pengelolaan Community Based Tourism

\begin{tabular}{cll}
\hline No & \multicolumn{1}{c}{ Faktor - Faktor } & \multicolumn{1}{c}{ Indikator } \\
\hline 1 & Kepuasan wisatawan & Kepuasan wisatawan dari berbagai aspek \\
\hline 2 & $\begin{array}{l}\text { Hubungan antar masyarakat satu } \\
\text { sama lain }\end{array}$ & $\begin{array}{l}\text { Berdasarkan pertemanan individu dan jaringan keluarga } \\
\text { anggota masyarakat. }\end{array}$ \\
\hline 3 & Keaslian lokal & Identitas budaya otentik dan warisan budaya yang unik \\
\hline 4 & Keunikan lokal & Tercipta perbedaan dengan objek wisata lain \\
\hline 5 & Kepemilikan lokal & Masyarakat sebagai pemilik sumber daya budaya dan alam \\
\hline 6 & Kepemimpinan lokal & $\begin{array}{l}\text { Pemimpin lokal mengelola, mengarahkan \& membangun } \\
\text { hubungan antara masyarakat dan stakeholders. }\end{array}$ \\
\hline 7 & Dukungan masyarakat & $\begin{array}{l}\text { Dukungan masyarakat dalam tahap perencanaan, } \\
\text { perangkulan, implementasi dan evaluasi keberhasilan CBT. }\end{array}$ \\
\hline 8 & Skala pengembangan pariwisata & $\begin{array}{l}\text { Pengembangan dan pengelolaan pariwisata sesuai dengan } \\
\text { prioritas, tuntutan, dan sumber daya masyarakat. }\end{array}$ \\
\hline 9 & Kerjasama antar stakeholders & Masyarakat dan stakeholders berkolaborasi. \\
\hline 10 & $\begin{array}{l}\text { Dukungan eksternal dari } \\
\text { stakeholders }\end{array}$ & $\begin{array}{l}\text { Stakeholders memberikan dukungan untuk meningkatkan } \\
\text { kapasitas }\end{array}$ \\
\hline & Sumber : IRTAD, 2017 &
\end{tabular}

\section{METODE}

Data yang dikumpulkan selama proses penelitian adalah profil desa adat Kutuh, profil Pantai Pandawa, sejarah perkembangan Pantai Pandawa, profil BUMDA, Struktur organisasi BUMDA dan unit pengelola usaha, Anggaran biaya dan kebijakan terkait Pantai Pandawa. Teknik pengumpulan data yang dilakukan dalam penelitian ini terbagi atas metode pengumpulan data primer dan pengumpulan data sekunder. Untuk metode pengumpulan data primer dilakukan dengan observasi/survei lapangan dan wawancara dengan pihak-pihak terkait. Sementara untuk metode pengumpulan data sekunder dilakukan dengan dokumentasi dan studi literatur.

Populasi (N) dari penelitian ini adalah pengunjung objek wisata Pantai Pandawa. Untuk pengambilan sampel $(\mathrm{n})$ dalam penelitian ini menggunakan teknik random sampling atau sampel acak. Responden yang akan mengisi kuesioner dalam penelitian ini adalah pengunjung Objek Wisata Pantai Pandawa yang akan dihitung jumlah samplenya menggunakan rumus slovin:

Keterangan :

$$
\mathrm{n}=\frac{N}{1+\left(N e^{2}\right)}
$$

$\mathrm{n}$ = Jumlah sampel

$\mathrm{N}=$ Jumlah Populasi

$\mathrm{E}=$ Persentase tingkat kesalahan dalam pengambilan sampel

Dengan jumlah pengunjung objek wisata Pantai Pandawa sebagai populasi (N), jumlah pengunjung pada tahun 2018 berdasarkan data dari Unit Usaha Pengelola Pantai Pandawa adalah sebanyak 1.982 .344 pengunjung dengan tingkat kesalahan dalam pengambilan sampel $10 \%$, maka diperoleh perhitungan jumlah sampel sebagai berikut :

$$
\begin{aligned}
& n=\frac{1.982 .344}{1+\left(1.982 .344 \times 0.1^{2}\right)} \\
& n=99,99
\end{aligned}
$$


Berdasarkan perhitungan diatas, didapatkan jumlah sampel yaitu 99,99 orang atau dibulatkan menjadi 100 orang. Untuk analisis yang dilakukan dalam penelitian ini adalah analisis kebijakan terkait objek wisata Pantai Pandawa, analisis daya tarik wisata yang dimiliki oleh Pantai Pandawa, analisis pengelolaan, analisis persepsi dan preferensi, analisis tolok ukur keberhasilan dan yang terakhir adalah analisis faktor - faktor penentu keberhasilan pengelolaan dengan berbasis community based. Secara keseluruhan alat analisis yang digunakan adalah metode deskriptif kualitatif. Menurut Nazir (2005), metode deskriptif kualitatif merupakan suatu metode yang digunakan untuk meneliti suatu objek, suatu sistem pemikiran ataupun suatu peristiwa yang terjadi pada masa sekarang.

\section{DISKUSI DAN HASIL}

\section{Analisis Kebijakan}

Analisis ini bertujuan untuk mengetahui apa saja kebijakan yang mengatur terkait Pantai Pandawa, sebagai acuan dalam keberhasilan pengelolaannya. Terdapat kebijakan - kebijakan baik dari pemerintah maupun dari pihak desa adat terkait Pantai Pandawa. Kebijakan terkait Pantai Pandawa yang diatur dalam peraturan pemerintah sebagai berikut :

1) Perda Kabupaten Badung No.26 tahun 2013 tentang RTRW Kabupaten Badung 2013 2033

Berdasarkan perda tersebut, Pantai Pandawa masuk dalam kawasan strategis dengan kepentingan fungsi dan daya dukung lingkungan hidup. Strategi yang dimiliki sebagai berikut :

a. Pengelolaan berpedoman pada Rencana Zonasi Wilayah Pesisir dan Pulau - Pulau Kecil (RZWP3K) yang ditetapkan dengan Peraturan Daerah;

b. pengembangan partisipasi masyarakat dalam memelihara kawasan pesisir dan laut;

c. pelestarian, perlindungan dan pengembangan terumbu karang.

2) Peraturan Bupati Badung No.43 tahun 2014 tentang Penetapan Pantai Pandawa sebagai Daya Tarik Wisata Kabupaten Badung

Berdasarkan peraturan Bupati tersebut, pengelolaan yang berlaku di kawasan Pantai Pandawa sebagai berikut :

a. Pengelolaan Daya Tarik Wisata yang dikerjasamakan pengelolaannya dengan Pemerintah Daerah dapat memungut retribusi Tempat Rekreasi dan berkewajiban menyetorkan ke Kas Daerah sesuai ketentuan peraturan perundang - undangan;

b. Pengelola sebagaimana dimaksud mendapatkan bagi hasil dari retribusi yang dipungut sesuai dengan ketentuan yang berlaku.

3) Peraturan Daerah Kabupaten Badung No.17 tahun 2016 tentang RIPPDA Kabupaten Badung 2017 - 2025

Berdasarkan perda tersebut, disebutkan dalam pasal 20 ayat (10) bahwa Pantai Pandawa masuk dalam Kawasan Pariwisata (KP) Nusa Dua, yang memiliki program pembangunan destinasi pariwisata sebagai berikut :

a. Peningkatan daya dukung wilayah untuk meningkatkan kualitas destinasi pariwisata berstandar internasional. Strateginya antara lain penataan daya tarik, pengembangan prasarana umum dan fasilitas umum, mitigasi dan adaptasi terhadap bencana, peningkatan kualitas DTW (Daya Tarik Wisata) yang bertaraf Internasional berbasis konservasi;

b. Peningkatan kualitas dan keragaman daya tarik wisata alam, budaya, dan buatan yang berbasiskan konservasi dan tradisi lokal. Strateginya antara lain diversifikasi DTW (Daya Tarik Wisata) berbasis potensi sumber daya alam dan budaya lokal, penataan zona pemanfaatan pantai, meningkatkan konservasi sumberdaya alam dan revitalisasi budaya lokal untuk menunjang kepariwisataan;

c. Optimasi manfaat ekonomi pariwisata bagi masyarakat, industri, dan pemerintah. Strateginya antara lain penguatan partisipasi juga akses dan kapasitas masyarakat lokal dalam kepariwisataan, mengembangkan sistem keamanan terpadu dan pelatihan 
keamanan juga pelayanan prima bagi petugas kemanan.

4) Peraturan Daerah Kabupaten Badung No.6 tahun 2016 tentang Retribusi Tempat Rekreasi dan Olahraga

Berdasarkan perda tersebut, Pantai Pandawa dikenakan retribusi tiket masuk wisata yang besarnya ditetapkan untuk kategori dewasa domestik sebesar Rp 8.000 per anak, dewasa mancanegara sebesar Rp 15.000 per anak. Untuk kategori anak - anak domestik sebesar Rp 4.000 per anak dan anak - anak mancanegara Rp 10.000 per anak.

Kebijakan terkait Pantai Pandawa yang diatur oleh pihak desa adat sebaagai berikut :

1) Peraturan Desa Adat Kutuh (BUMDA) dengan Pemerintah Kabupaten Badung tentang Pengelolaan Tempat Rekreasi Obyek/ DTW Pantai Pandawa Desa Kutuh.

Berdasarkan peraturan tersebut, mengatur tentang pengelolaan dan pembagian hasil retribusi. Tujuannya adalah untuk memelihara, melestarikan, upaya optimalisasi pengelolaan dan meningkatkan pendapatan melalui diberlakukannya retribusi tempat rekreasi oleh pemerintah. Dimana hak dan kewajiban dari pemerintah yang pelaksanaannya dilimpahkan ke Dinas Pariwisata Kab.Badung adalah sebagai berikut:

a. Melakukan pembinaan manajemen pengelolaan dan membantu melengkapi infrastruktur, sarana dan prasarana;

b. Wajib mensosialisasikan peraturan perundang - undangan yang berlaku yaitu retribusi DTW;

C. Wajib mendistribusikan dana hasil pungutan retribusi ke Bendesa Adat Kutuh sebesar $75 \%$ awal bulan berikutnya berdasarkan setoran Bendesa Adat Kutuh secara tunai/lunas ke Kas Daerah melalui BPD Bali;

d. Wajib memfasilitasi karcis DTW;

e. Berhak mengarahkan sistem pungutan, penyetoran, pengelolaan, pemanfaatan dan pertanggung jawaban retribusi DTW.

2) Peraturan Desa Adat Kutuh (BUMDA) dengan PT. Agung Aquatic Marine tentang Percepatan Pengembangan Kawasan Konservasi Terumbu Karang Perairan Pantai Pandawa Tujuannya adalah untuk melakukan pengembangan pelestarian terumbu karang (transplantasi) di kawasan perairan pandawa untuk tujuan pengembangan pengembangan usaha dan wisata tirta. Dimana hak dan kewajiban dari PT Agung Aquatic Marine adalah sebagai berikut:

a. Membantu mempercepat mewujudkan kawasan konservasi berbasis transplantasi dengan memberdayakan masyarakat lokal, memonitor, mengevaluasi dan memberikan umpan balik terhadap kegiatan yang dilakukan

b. Berhak melakukan kegiatan budidaya, penjualan, promosi, atau kegiatan

3) Peraturan Desa Adat Kutuh (BUMDA) dengan PT. Alam Bali Internasional tentang Pengembangan Usaha Pariwisata Pada Kawasan Wisata Terpadu Pantai Pandawa

Tujuannya adalah untuk bersama - sama bersinergi menjadikan DTW (Daya Tarik Wisata) Pantai Pandawa berdaya guna dan berdaya nilai, b. Memberdayakan personal Pecalang Trepti Jaga Buana Desa Adat Kutuh sebagai bagian dari Bhaga Panyukerta Desa Adat Kutuh. Adapun hak dan kewajiban dari PT Alam Bali Internasional adalah sebagai berikut :

a. Membayar dana partisipasi pembangunan awal untuk alih fungsi lahan \& administrasi ilikita persetujuan sebesar Rp 2.000.000 per-are untuk seluruh lahan usaha

b. wajib membayar dana partisipasi pengamanan kawasan setiap bulan selama perjanjian setara dengan $500 \mathrm{~kg}$ beras (Rp 5.000.000) dan disesuaikan dengan perkembangan harga beras

c. Wajib memanfaatkan minimal 1 tenaga pengamanan desa adat untuk internal usaha dengan gaji yang standar diberlakukan

d. Wajib membayar labda desa setiap than ke Desa Adat Kutuh sebagai partidipasi pengembangan kawasan pantai pandawa yaitu sebesar $10.000 \mathrm{~kg}$ beras (Rp 100 juta) 
harga disesuaikan dengan harga beras. Dan disetorkan awal tahun paling lambat bulan maret ke rekening Desa Adat Kutuh

e. Wajib membayar dana retribusi parkir dan tiket masuk kawasan atas kunjungan setiap tamu

f. Bekerjasama mempromosikan pantai pandawa

\section{Analisis Daya Tarik}

1) What to see

Pantai Pandawa memiliki pemandangan alam berupa pasir putih dan laut biru, tebing karst, dan patung pandawa lima.
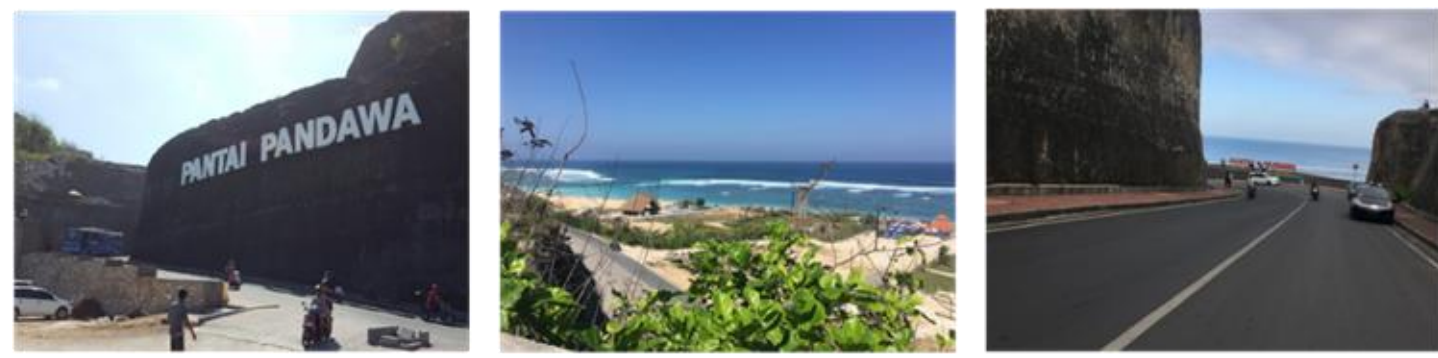

Gambar 1. Foto - Foto Eksisting Pantai Pandawa

Sumber: Penulis, 2019

2) What to do

Di Pantai Pandawa terdapat kegiatan yang dapat dilakukan seperti wisata air kano, wisata konservasi terumbu karang, wisata budaya tari kecak, tari lepas dan tari barong juga terdapat event setiap akhir tahun yaitu event Festival Pantai Pandawa.

3) What to buy

Terdapat oleh - oleh khas Bali yang dapat para pengunjung beli di Pantai Pandawa seperti kue pie susu, kue pia barong, kacang disko, sovenir topi pantai, gantungan kunci, tas rotan, baju barong dan ikat kepala udeng.

4) What to arrived

Aksesibilitas menuju Pantai Pandawa mudah karena memiliki tiga alternatif rute, yaitu rute via Jl. Bali Clif, Jl. Goa Gong dan via tol Bali Mandara. Ketiga rute ini dapat dilalui oleh berbagai jenis moda transportasi dan tidak ada transportasi umum yang melewati Pantai Pandawa sehingga direkomendasikan menggunakan kendaraan pribadi. Pantai Pandawa juga memiliki lokasi yang strategis karena berada di antara kawasan pariwiata Uluwatu, GWK dan Nusa Dua. Disekitar Pantai Pandawa juga banyak fasilitas pendidikan seperti Universitas Udaya dan STP Nusa Dua.
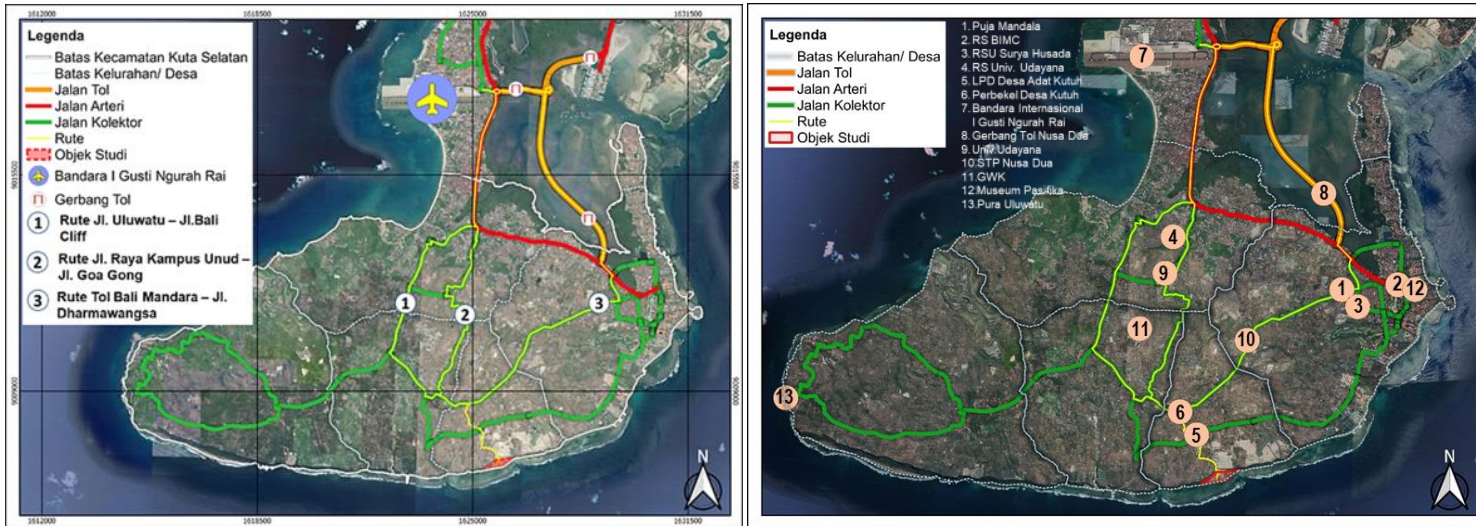

Gambar 2. Peta Aksesibilitas (kiri) dan Peta Persebaran Pusat Kegiatan (kanan) Sumber: Penulis, 2019 
5) What to stay

alam radius $2 \mathrm{~km}$ sudah terdapat sekitar 18 penginapan berupa hotel, homestay hingga villa. Harga per malam yang ditawarkan juga bervariasi mulai dari Rp 180.000 hingga Rp 33.000.000. Berikut adalah Daftar persebaran penginapan dalam radius $2 \mathrm{~km}$ dari Pantai Pandawa :

Tabel 2. Daftar Penginapan dalam Radius 2 km dari Pantai Pandawa

\begin{tabular}{clc}
\hline No & \multicolumn{1}{c}{ Nama Penginapan } & Harga Per malam (Rp) \\
\hline 1 & Frangipani Villa & 16.600 .000 \\
\hline 2 & Indigo Dream Villa & 1.700 .000 \\
\hline 3 & Puri Pandawa Resort & 800.000 \\
\hline 4 & Villa The Cliff Hotman Paris VI & 8.600 .000 \\
\hline 5 & Resort Nusa Dua Retreat & 1.500 .000 \\
\hline 7 & Pandawa Beach Homestay & 260.000 \\
\hline 8 & Paanchali Villa & 2.200 .000 \\
\hline 9 & Ocho Bali Bungalow & 3.000 .000 \\
\hline 10 & Green Bowl Bali Homestay & 350.000 \\
\hline 11 & Hotel Pandawa Hill & 280.000 \\
\hline 12 & Dinar Hills Villa & 350.000 \\
\hline 13 & Ady Homestay Pandawa & 500.000 \\
\hline 14 & Villa Bidadari & 200.000 \\
\hline 16 & Lala Homestay & 3.300 .000 \\
\hline 17 & Villa Karang Kembar & 180.000 \\
\hline 18 & Pondok Kedongdong Homestay & 33.000 .000 \\
\hline
\end{tabular}

Sumber: Hasil Olahan Penulis, 2019

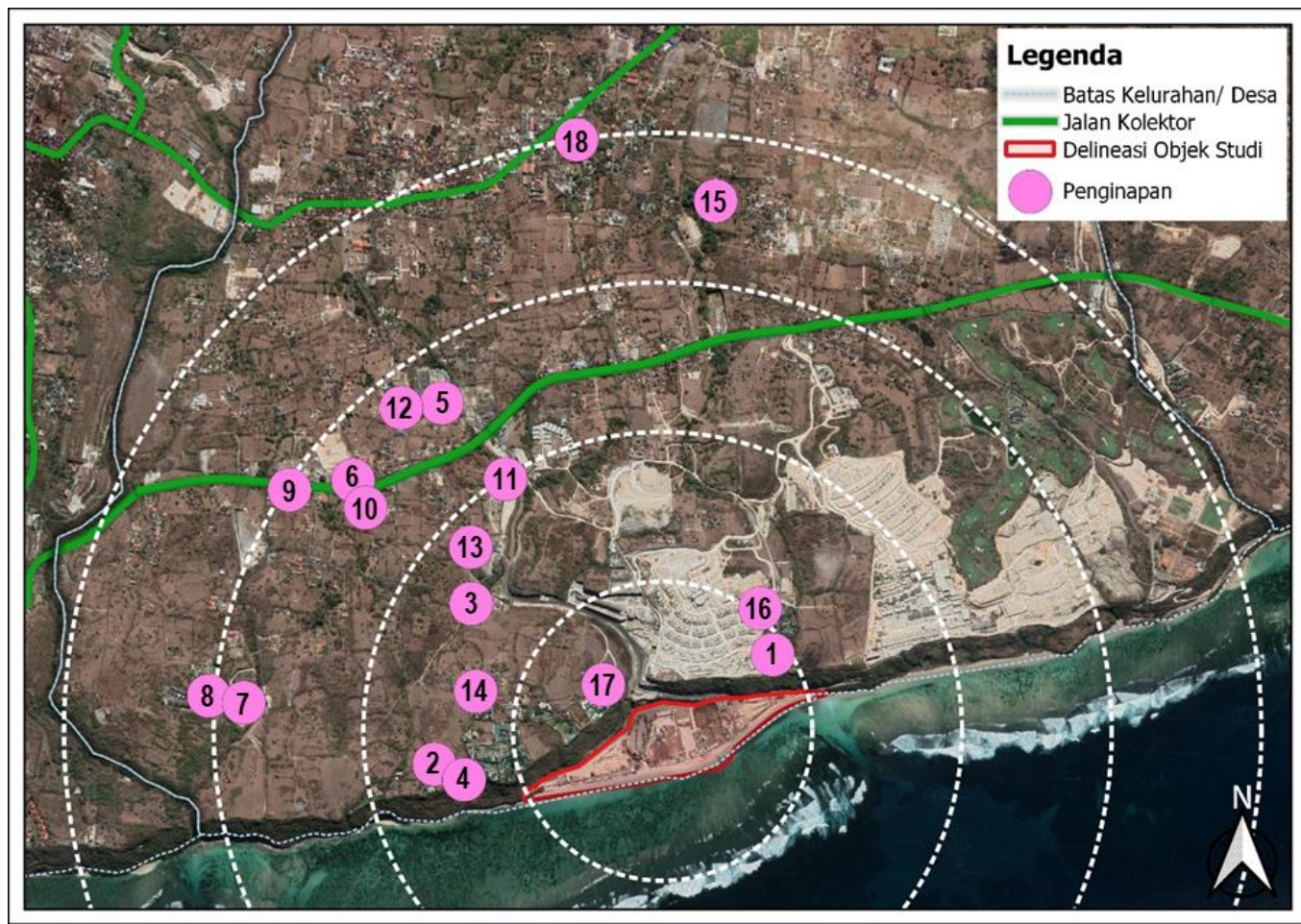

Gambar 3. Peta Persebaran Penginapan dalam Radius 2 km dari Pantai Pandawa Sumber: Hasil Olahan Penulis, 2019 


\section{Analisis Pengelolaan}

Pantai Pandawa saat ini dikelola oleh BUMDA Kutuh melalui pengelola unit usaha Pantai Pandawa. Pengelola unit usaha Pantai Pandawa memiliki struktur organisasi formal dengan susunan Manager, Kepala Tata Usaha, Bendahara, Kepala Bagian Perencanaan dan Pengembangan Kawasan, Kepala Bagian Promosi SDM Kerjasama dan Humas, Kepala Bagian Tiketing dan Pungutan, Kepala Divisi Parkir dan Keamanan, Koordinator Lifeguard, dan Kepala Divisi Pertamanan dan Kebersihan. Masing - masing bagian memiliki jobdesc dan untuk setiap kepala bagian memiliki staf dibawahnya.

\section{Analisis Persepsi dan Preferensi}

Berdasarkan preferensi penunjung untuk kegiatan wisata dan fasilitas yang perlu ditambahkan di Pantai Pandawa yaitu Wisata Edukasi Kesenian Bali dan Wisata Edukasi Marine Park untuk kegiatan wisata tambahan. Penambahan toilet bersih dan penambahan café/beach club untuk fasilitas tambahan.

Sedangkan berdasarkan persepsi pengunjung tentang kondisi dan kinerja dari fasilitas yang ada di Pantai Pandawa dengan menggunakan diagram cartesius, diketahui bahwa yang terdapat pada Kuadran I yaitu fasilitas - fasilitas yang harus di prioritaskan tingkat kinerja dan kondisinya karena memiliki kepentingan yang tinggi bagi pengunjung adalah ketersediaan toilet umum, kebersihan toilet umum, kenyamanan toilet umum, ketersediaan gazebo, ketersediaan ATM Center, ketersediaan penginapan sekitar, wisata edukasi konservasi terumbu karang, dan wisata long chair. Berdasarkan kepuasan pengunjung terhadap Pantai Pandawa menggunakan metode CSI (Customer Satisfaction Index) diketahui sebesar 62,25\% pengunjung puas atas seluruh aspek - aspek seperti prasarana, administrasi, fasilitas dan wisata yang ada di Pantai Pandawa.

\section{Analisis Tolok Ukur Keberhasilan Community Based Tourism}

Berdasarkan Suansri (2003), pengelolaan berbasis community based tourism pada objek daya tarik wisata Pantai Pandawa dikatakan berhasil apabila memenuhi lima aspek yaitu ekonomi, sosial, budaya, lingkungan dan politik. Dengan indikator dari masing - masing aspek sebagai berikut ini :

Tabel 3. Tolok Ukur Keberhasilan Pengelolaan Community Based Tourism

\begin{tabular}{cl}
\hline Aspek & \multicolumn{1}{c}{ Indikator } \\
\hline \multirow{2}{*}{ Ekonomi } & Tersedia dana untuk pengembangan komunitas \\
\cline { 2 - 2 } & Terciptanya lapangan pekerjaan dan pendapatan masyarakat di sektor pariwisata \\
\hline Sosial & Adanya penguatan organisasi komunitas \\
\hline Budaya & Pelestarian keunikan karakter dan budaya di area lokal \\
\hline Lingkungan & Adanya konservasi untuk menjamin keberlanjutan lingkungan \\
\hline Politik & Adanya partisipasi masyarakat lokal \\
\hline
\end{tabular}

Sumber : Suansri, 2013

Dalam pengelolaannya, Pantai Pandawa telah memenuhi seluruh indikator. Indikator yang paling penting yaitu dari aspek ekonomi, dimana seluruh keuntungan dari objek wisata Pantai Pandawa untuk kesejahteraan masyarakat desa adat Kutuh sendiri yaitu sebesar $10 \%$ dana dari keuntungan Pantai Pandawa dialokasikan untuk dana pembinaan (5\%) dan dana sosial (5\%). Berdasarkan hasil wawancara dengan masyarakat lokal dan pihak pengelola, sebelum diresmikannya pantai pandawa sebagai objek wisata, mata pencaharian dominan warga masyarakat Desa Kutuh adalah sebagai petani rumput laut dan petani ladang hingga sayur. Namun setelah dibukanya objek wisata pantai pandawa, dan rumput laut mulai tidak panen, $90 \%$ warga setempat beralih profesi menjadi pelaku usaha, hal ini membuktikan bahwa 
dengan dibukanya Pantai Pandawa sebagai objek wisata juga ikut menciptakan lapangan pekerjaan bagi masyarakat lokal yang memiliki dampak berupa timbulnya pendapatan masyarakat setempat.

Dalam aspek sosial, Pantai Pandawa juga sudah diperkuat pengelolaannya dengan memiliki pengelola yang disebut Pengelola Unit Usaha Pantai Pandawa. Seluruh sumber daya manusia yang dimiliki organisasi tersebut berjumlah 78 orang berasal dari masyarakat asli Desa Adat Kutuh. Pengelola juga melakukan pembinaan dan pelatihan terhadap seluruh SDM, memiliki program dalam mengapresiasi para pegawainya, memiliki sop untuk pegawai, memiliki rencana kerja dan melakukan evaluasi kinerja setiap awal tahun. Pengelola unit pantai pandawa bertanggung jawab atas pengelolaan dan pengembangan fasilitas, ticketing, biaya operasional, dan gaji pegawai, memiliki event rutin tahunan seperti festival pantai pandawa dalam rangka promosi, memiliki kemitraan kerja dengan pihak ketiga terkait keselamatan maupun kerjasama pariwisata, serta memiliki program pembinaan terhadap usaha kelompok.

Dalam aspek budaya yaitu tetap melekatnya keunikan karakter dan budaya. Dalam hal ini pengelola unit tetap melestarikan budaya yang menjadi keunikan dari Pantai Pandawa yaitu pura - pura suci yang ada di dalam area pantai, dan kegiatan upacara melasti. Keduanya tersebut merupakan hal suci yang melekat dan menjadi bagian dari masyarakat desa adat kutuh itu sendiri. Pura pura suci yang terdapat di dalam kawasan pantai tersebut dijaga kesuciannya namun juga menjadi bagian dari wisata spiritual ketika ada kegiatan upacara melasti di Pantai Pandawa. Kegiatan upacara melasti juga tetap dilaksanakan ketika akan memasuki hari nyepi. Pengelola unit menjadikan upacara melasti sebagai daya tarik wisata spiritual tersendiri. Selain itu, terdapat keunikan yang menjadi ciri khas dari pantai pandawa yang tidak ada di DTW (Daya Tarik Wisata) lain yaitu patung pandawa lima.

Dalam aspek lingkungan, yaitu adanya konservasi untuk menjamin keberlangsungan lingkungan. Dalam hal ini pengelola pusat (BUMDA Kutuh) telah memiliki kebijakan yang dibuat oleh BUMDA Kutuh dengan PT. Agung Aquatic Marine tentang Percepatan Pengembangan Kawasan Konservasi Terumbu Karang Perairan Pantai Pandawa. Hal ini merupakan wujud keseriusan dari pengelola pusat maupun unit dalam mewujudkan kawasan konservasi berbasis transplantasi dengan memberdayakan masyarakat lokal.

Dalam aspek politik, bentuk partisipasi masyarakat yang dimiliki oleh masyarakat Desa Adat Kutuh yaitu partisipasi spontan karena muncul atas inisiatif masyarakat Desa Adat Kutuh itu sendiri. dibuktikan pada tahap perencanaan dimana masyarakat ikut dalam identifikasi masalah, seperti masyarakat setempat yang awalnya mengusulkan kepada Bendesa Adat Kutuh dan Perbekel Kutuh untuk membuka akses menuju Pantai Pandawa untuk kemudahan para petani rumput laut dan upacara melasti. Partisipasi spontan juga ditandai dengan masyarakat terlibat sebagai pembuat keputusan yang dibuktikan dalam pembentukan kelembagaan desa adat BUMDA Kutuh dan manajemen pengelolaan unit ussaha pantai pandawa yang seluruh karyawannya merupakan masyarakat asli desa adat kutuh, seluruh komponen masyarakat desa adat kutuh terlibat dan punya peran masing-masing sesuai kapasitasnya.

\section{Analisisi Faktor - Faktor Keberhasilan Community Based Tourism}

Berdasarkan penelitian sebelumnya, yaitu dalam jurnal penelitian International Rural Tourism and Development Journal (IRTAD) yaitu tentang Success Factors of Community Based Tourism (CBT) Perceived by Local Peoples (2017), diketahui terdapat sepuluh faktor sukses keberhasilan utama dari pengelolaan berbasis community based tourism. Berikut merupakan faktor - faktor keberhasilan pengelolaan berbasis community based tourism : 
Tabel 4. Faktor - Faktor Keberhasilan Pengelolaan Community Based Tourism

\begin{tabular}{|c|c|c|}
\hline No & Faktor - Faktor & Indikator \\
\hline 1 & Kepuasan wisatawan & Kepuasan wisatawan dari berbagai aspek \\
\hline 2 & $\begin{array}{l}\text { Hubungan antar masyarakat satu } \\
\text { sama lain }\end{array}$ & $\begin{array}{l}\text { Berdasarkan pertemanan individu dan jaringan keluarga } \\
\text { anggota masyarakat. }\end{array}$ \\
\hline 3 & Keaslian lokal & Identitas budaya otentik dan warisan budaya yang unik \\
\hline 4 & Keunikan lokal & Tercipta perbedaan dengan objek wisata lain \\
\hline 5 & Kepemilikan lokal & Masyarakat sebagai pemilik sumber daya budaya dan alam \\
\hline 6 & Kepemimpinan lokal & $\begin{array}{l}\text { Pemimpin lokal mengelola, mengarahkan \& membangun } \\
\text { hubungan antara masyarakat dan stakeholders. }\end{array}$ \\
\hline 7 & Dukungan masyarakat & $\begin{array}{l}\text { Dukungan masyarakat dalam tahap perencanaan, } \\
\text { perangkulan, implementasi dan evaluasi keberhasilan CBT. }\end{array}$ \\
\hline 8 & Skala pengembangan pariwisata & $\begin{array}{l}\text { Pengembangan dan pengelolaan pariwisata sesuai dengan } \\
\text { prioritas, tuntutan, dan sumber daya masyarakat. }\end{array}$ \\
\hline 9 & Kerjasama antar stakeholders & Masyarakat dan stakeholders berkolaborasi. \\
\hline 10 & $\begin{array}{l}\text { Dukungan eksternal dari } \\
\text { stakeholders }\end{array}$ & $\begin{array}{l}\text { Stakeholders memberikan dukungan untuk meningkatkan } \\
\text { kapasitas }\end{array}$ \\
\hline
\end{tabular}

Berdasarkan faktor - faktor keberhasilan pengelolaan community based tourism terdahulu tersebut, maka akan di sesuaikan antara teori dengan keadaan eksisting yang dimiliki oleh pengelola Pantai Pandawa. Maka didapatkan tiga faktor terkuat dari keberhasilan pengelolaan Pantai Pandawa oleh BUMDA Kutuh sebagai berikut:

a. Kepemimpinan Lokal

Dimana pemimpin lokal yang mengelola, dan juga mengarahkan serta membangun hubungan antara anggota masyarakat dan pemangku kepentingan lainnya terkait pembangunan dan pengelolaan Pantai Pandawa. Pemimpin lokal yang dimaksud yaitu Bendesa Adat Kutuh, yang dalam struktur organisasi pengelolaan merupakan direktur utama dari BUMDA Kutuh. Bendesa Adat Kutuh selalu aktif sebagai tokoh penggerak yang mengarahkan dan mengimplementasikan setiap rencana, menjadi koneksi antara masyarakat dengan stakeholder dalam mencapai mufakat.

b. Dukungan Masyarakat

Dukungan yang kuat oleh masyarakat Desa Adat Kutuh itu sendiri. Dimana pengelola pusat maupun unit yang terdiri dari masyarakat asli desa adat yang direkrut menjadi pegawai. Namun bagi masyarakat setempat ikut berpartisipasi pada tahap perencanaan dan menikmati hasil, karena untuk tahap pelaksanaan dan evaluasi dilakukan oleh pihak manajemen.

c. Kerjasama antar stakeholders

Stakeholders terkait pengelolaan pantai pandawa melibatkan masyarakat, pemerintah, pihak swasta. Peran masyarakat sebagai pelaku usaha, pemerintah Sebagai regulator, dinamisator dan fasilitator, dan pihak swasta sebagai mitra. Dukungan dari stakeholders pihak swasta selaku mitra yaitu dari akademisi berupa pelatihan bahasa asing dan materi manajemen. Dari pihak swasta berupa pemberdayaan dan pembinaan untuk kegiatan pariwisata. Dan dari pihak pemerintah berupa kebijakan - kebijakan yang mendukung perkembangan dari pada Pantai Pandawa.

\section{KESIMPULAN DAN SARAN}

\section{Kesimpulan}

Kesimpulan yang diperoleh berdasarkan hasil penelitian ini adalah :

1) Pantai Pandawa memiliki daya tarik wisata alam, seperti pemandangan pasir putih dan laut biru, tebing karst dan patung pandawa lima serta upacara melasti yang menjadi daya tarik 
khusus yang berbeda dengan tempat lain. Terdapat empat macam kegiatan berupa wisata air kano, wisata budaya tari kecak, tari lepas dan tari barong, wisata edukasi konservasi terumbu karang, dan event festival pantai pandawa setiap akhir tahun dilakukan selama satu minggu. Di kawasan pantai pandawa sudah tersedia oleh - oleh dan cinderamata khas bali yang dijual. Aksesibilitas menuju pantai pandawa mudah hanya menempuh jarak sekitar 18 km dengan waktu tempuh sekitar 30 menit dari bandara I Gusti Ngurah Rai menggunakan kendaraan pribadi. Lokasi nya juga strategis karena berdekatan dengan fasilitas kesehatan, fasilitas pendidikan dan objek wisata penting lainnya seperti Garuda Wisnu Kencana, Kawasan Nusa Dua dan Uluwatu. Hingga saat ini dalam radius hingga $2 \mathrm{~km}$ dari pantai pandawa tersedia sebanyak 18 penginapan dengan harga dari $\mathrm{Rp} 180.000$ hingga Rp 33.000.000 per malam.

2) Pantai Pandawa merupakan sebuah unit usaha berorientasi bisnis yang dikuasai dan dimiliki oleh masyarakat asli desa adat kutuh sebagai asset juga potensi desa. Saat ini pantai pandawa pengelolaannya diintegrasikan kepada manajemen unit usaha melalui lembaga desa adat BUMDA yang merupakan manajemen pusat (holding company) dari 8 unit usaha. Manajemen unit usaha tersebut dinamakan pengelola unit usaha pantai pandawa, yang sudah memiliki struktur organisasi yaitu memiliki manager, kepala tata usaha, bendahara dan 5 kepala divisi yang masing - masing memiliki staf seluruhnya sudah bekerja sesuai dengan jobdescnya masing - masing. Pengelola unit usaha pantai pandawa juga sudah memiliki rencana kerja dalam satu tahun kedepan setiap tahunnya.

3) BUMDA Kutuh dan manajemen unit usaha Pantai pandawa berhasil mengelola pantai pandawa dengan berbasis community based tourism. Keberhasilan pengelolaan berbasis community based tourism diukur dari berhasilnya pihak pengelola dalam mengelola dana kolektif untuk kesejahteraan masyarakat desa adat kutuh, adanya kegiatan pariwisata pantai pandawa menciptakan lapangan pekerjaan bagi masyarakat setempat, pembentukan manajemen unit usaha oleh BUMDA memperkuat pengoptimalan pengelolaan pantai pandawa, budaya upacara melasti dan indentitas kawasan tetap terjaga dan diminati banyak pengunjung, adanya kegiatan konservasi yang digalakkan dan partisipasi masyarakat setempat yang tinggi dan tanpa paksaan.

4) Keberhasilan BUMDA Kutuh dan manajemen unit dalam pengelolaannya dipengaruhi oleh beberapa faktor antara lain kepuasan pengunjung terhadap aspek prasarana, administrasi, fasilitas dan wisata yang ditawarkan, faktor hubungan masyarakat adat satu dengan lainnya, faktor kepemilikan lokal, kepemimpinan lokal, dukungan masyarakat, skala pengembangan kawasan, peran dan dukungan dari pemangku kepentingan.

\section{Saran}

Saran yang dapat diberikan berdasarkan hasil penelitian ini adalah :

1) Pengelola unit usaha Pantai Pandawa perlu membuat program pencegahan dan penanggulangan kebakaran.

2) Pengelola unit usaha Pantai Pandawa perlu membuat program keselamatan kesehatan kerja (K3).

3) Pengelola unit usaha Pantai Pandawa perlu membuat program pemeriksaan kesehatan berkala untuk para karyawan maupun masyarakat yang menjadi pelaku usaha.

4) Pengelola unit usaha Pantai Pandawa perlu memperbaiki dan meningkatkan fasilitas penunjang yang kurang baik.

5) Pengelola unit usaha Pantai Pandawa perlu memberikan kesempatan edukasi tentang pelatihan wirausaha kepada masyarakat desa adat lain yang tidak menjadi pelaku usaha.

6) Pengelola pusat BUMDA Kutuh perlu untuk memberikan kewenangan pengelolaan fasilitas lebih dari $25 \%$ untuk optimalisasi pengelolaan kawasan oleh manajemen unit. 


\section{REFERENSI}

Badan Pusat Statistik. (2018). Desember 2018: Hasil Pendataan Potensi Desa (Podes) 2018. Diakses 17 Oktober 2019, dari https://www.bps.go.id/pressrelease/2018/12/10/1536/hasilpendataan-potensi-desa--podes--2018.html.

Hadiwijoyo, S. S. (2012). Perencanaan Pariwisata Perdesaan Berbasis Masyarakat (Sebuah Pendekatan Konsep). Yogyakarta : Graha Ilmu.

Karacaoglu, S. \& Birdir, K. (2017). Success Factors of Community Based Tourism (CBT)

Maryani. (1991). Pengantar Geografi Pariwisata. Bandung: Jurusan Pendidikan Geografi FPIPS IKIP.

Nazir, M. (2005). Metode Penelitian. Jakarta: Ghalia Indonesia

Pengelola Unit Usaha Pantai Pandawa. (2018). Rencana Kerja Anggaran Pendapatan Dan Belanja : Pengelola Unit Usaha Pantai Pandawa.

Perceived by Local Peoples: The Case of \% 100 Misia Project. International Rural Tourism and Development Journal, 1 (2): 53-61.

Spillane, J.J. (1987). Pariwisata Indonesia Sejarah dan Prospeknya. Yogyakarta : Kanisisus.

Suansri, P. (2003). Community Based Tourism Handbook. Thailand: REST Project

Undang Undang tentang Kepariwisataan, UU No. 10 Tahun 2009. Jakarta: Direktorat Jenderal Hukum dan HAM. 
